\title{
Current Developments of Legal Instruments to Prevent and Control of Pollution In The Straits of Malacca
}

\author{
Pulung Widhi Hari Hananto \\ Fakultas Hukum, Universitas Diponegoro \\ pulungharihanan@lecturer.undip.ac.id
}

\begin{abstract}
The Strait of Malacca is one of the busiest straits in the world with more than 60,000 vessels through the strait per year. This strait is located in strategic location to connect west part and east part of the world. However, number of vessels transit and pass through the strait has effect on marine environmental issues. Pollution, especially vessel-based sources, may affect marine life. To settle the issues along with the boundary issue, Indonesia, Malaysia and Singapore have entered into some agreements to cooperate to manage the Strait of Malacca since 1970s. Recently, the concept of Cooperative Mechanism has been developed. Several meetings amongst these states have been done with some positive deals. With this concept, the littoral states believe that it can prevent, reduce and control of marine pollution in the Strait of Malacca. However, more progress is still needed to enhance from the implementation of the Cooperative Mechanism.
\end{abstract}

Keywords: Strait of Malacca, Pollution, Marine, Environment, Cooperative Mechanism.

\section{A. Introduction}

Strait of Malacca connects the Indian Ocean through Andaman Sea on the North and the South China Sea through the Straits of Singapore on the south. Extend approximately $800 \mathrm{~km}$ (500 miles) along the east coast of Sumatra and the west coast of Peninsular Malaysia makes it the longest straits used for international navigation. (Mokhzani Zubir, 2004 ; Nazery Khalid, 2009). The starting point of the straits is actually from the north-west by line from Ujung Baka i.e. the north-west edge of Sumatra $\left(5^{\circ} 400 \mathrm{~N}, 95^{\circ} 260 \mathrm{E}\right)$ to Laem Phra Chao the south edge of Ko Phuket Island Thailand $\left(7^{\circ} 450 \mathrm{~N}\right.$, $98^{\circ} 180 \mathrm{E}$ ). Meanwhile the end point of the straits is on the south-east by line from Tahan (Mount) Datok $\left(1^{\circ} 200 \mathrm{E}, 104^{\circ} 200 \mathrm{~N}\right)$ and Tanjung Pergam $\left(1^{\circ} 100 \mathrm{E}, 104^{\circ} 200 \mathrm{~N}\right)$. (Chua Thia-Eng et al., 2000)

Picture 1.1: Strait of Malacca

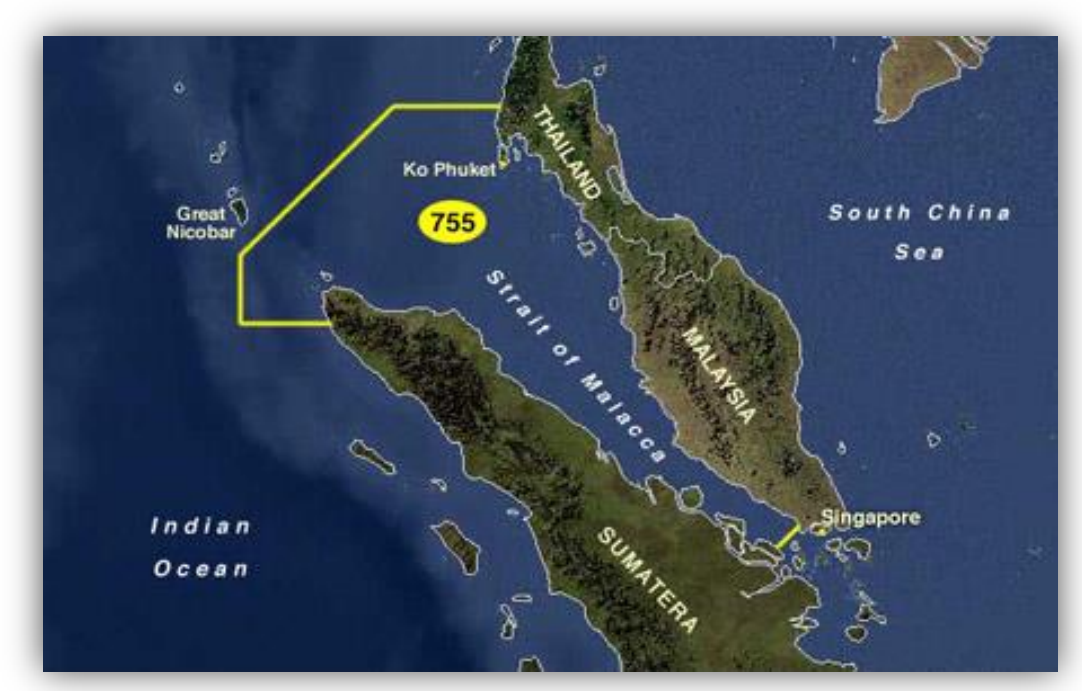


The world's map shows that the Straits of Malacca connecting the Indian Ocean and the South China Sea, which are used for international navigation, thus all ships enjoy the right of transit passage through the Straits of Malacca. Regime of transit passage under UNCLOS provides freedom of navigation to all ships includes military ships carried with it nuclear or any types of hazardous cargo to pass through straits used for international navigation. There are three basic elements for transit passage. First, the water must be strait. Second, strait must be used for international navigation and third, transit should be expeditious. (Abdul Haseeb, 2005). The states bordering straits or littoral states have no power to suspend the transit passage. (UNCLOS, Article 44). However, free passage through international straits raised another issue. Due to economic and environmental aspects, littoral states might hesitate to allow foreign ships to pass freely through straits which will harmful to their economies and marine environments without additional conditions. This issue is resolved by allowing more freedom for transiting ships than they enjoyed under innocent passage but less freedom than they enjoyed on the high seas. (Jeanine B. Womble, 2012).

Under UNCLOS, right to transit passage must be exercised solely for the purpose of continuous and expeditious transit of the straits. As stated before, right to transit passage shall not be suspended. However, any activity which is not an exercise of transit passage remains subject to the other applicable provisions of the Convention. (UNCLOS, article 38(2) and (3)). Other applicable provisions referred to is rules on innocent passage. (UNCLOS, article 45). All vessels must comply with internationally accepted regulations, procedures and practices for safety at sea and for the prevention, reduction and control of pollution from vessels. (Abdul Haseeb, 2005). In the event where a ship not exercising its right of transit passage in the straits used for international navigation, the general regime of innocent passage will be applicable. (R.R. Churchill \& A.V. Lowe, 1999). UNCLOS empowered the littoral states to deny passage and may take necessary steps to prevent passage which that deems to be prejudicial to their peace, good order and security. (UNCLOS, article 45). Thus, Straits of Malacca actually consists of two legal regimes i.e. the transit passage regime and the innocent passage regime. The regime of innocent passage occurred within the territorial sea of coastal states.(Nazery Khalid, 2009).

For the purpose of this paper, Article 19(2)(h) of UNCLOS provides that passage of a foreign ship shall be considered to be prejudicial to the peace, good order or security of the coastal state if the ship engage in any act of wilful and serious pollution contrary to this convention. Pursuant to this article, Article 233 of Part XII laid some exception to the non-suspension of vessels transiting through the straits used for international navigation. States bordering straits can suspend passage of foreign vessels if the passage causes major damage to the marine environment of such straits. (Mohd Hazmi, 2012).

Although the present status of Straits of Malacca is recognised as straits used for international navigation coupled with innocent passage, there is history behind this recognition. Before the UNCLOS 
came into force, Indonesia and Malaysia refused to acknowledge the status of Straits of Malacca as high seas and an international straits as this will hinder their right to impede ships transiting the straits. Thus, in March 1970 these states signed a treaty to draw their maritime boundaries and granted only right to innocent passage for user states. By granting innocent passage, the sovereignty right of the coastal states is more secured where they have right to suspend the innocent passage if their security is threatened. United States and the Soviet Union felt unsecured and burdened with this treaty make a bargain to recognise Malaysia's and Indonesia's claims of 12 nautical miles of territorial sea in exchange of transit passage rights through the Straits of Malacca. Both states accepted this compromise and restore the status of Straits of Malacca as straits used for international navigation. The result of the agreement is that the straits contained two legal regime of transit passage and innocent passage as the states obtained its 12 nautical miles of territorial sea. The regime of transit passage however prevails over the innocent passage rights. (Carrie R. Wooley, 2010)

Tracing back the historical background of Strait of Malacca in the 16th century, it has more than for hundreds years benefiting people around the world. It serves as sea route and facilitates the travels of people. As it provides economic links with the outside world, the world had witnessed a succession of kingdoms along the Straits of Malacca. From the Srivijaya Empire and the Malacca Sultanate to European colonialists, all these power became outstanding maritime empires due to its strategic ports alongside the Strait of Malacca. The Straits of Malacca was the major contributors to prosperity during that time. (S Jayakumar, 1998).

In the present day Strait of Malacca is one of the busiest straits in the world used for international trade and transportation. This strait becomes the most strategic and important shipping lanes as it shortened the ship's course navigates from the east continent to the west continent of the world and vice versa. It is recorded that in a year more than 60,000 vessels passing through the straits. Half of the world's oil flows and one-third world's sea-borne trade is actually carried through this strait. Countries like China, Japan and Korea that have to imports most of their raw materials and energy are very much dependent on the Straits of Malacca as much of their trade and energy imports are transported through this straits from the Middle East. (H.M Ibrahim \& Nazery Khalid, 2007).

\section{B. Discuss and Result}

\section{International And National Legal Framework To Prevent, Reduce And Control Of Pollution}

In general, marine pollution is regulated in UNCLOS III 1982. According to Article 1 of UNCLOS III 1982. This definition is based on definition determined by UNESCO's Inter-governmental Oceanographic Commission and the UN's Group Experts on the Scientific Aspects of Marine (GESAMP) (R.R. Churchill and A. V. Lowe, 1999). The definition of marine pollution is as follows: "Pollution of the marine environment" means the introduction by man, directly or indirectly, of substances or energy into the marine environment, including estuaries, which results or is likely to result in such deleterious effects as harm to living resources and marine life, hazards to human health, 
hindrance to marine activities, including fishing and other legitimate uses of the sea, impairment of quality for use of sea water and reduction of amenities.

Article 1 also defines "dumping" which has relation to marine pollution. The definition of dumping is as follows:

(a) "dumping" means:

(i) any deliberate disposal of wastes or other matter from vessels, aircraft, platforms or other man-made structures at sea;

(ii) any deliberate disposal of vessels, aircraft, platforms or other man-made structures at sea;

(b) "dumping" does not include:

(i) the disposal of wastes or other matter incidental to, or derived from the normal operations of vessels, aircraft, platforms or other man-made structures at sea and their equipment, other than wastes or other matter transported by or to vessels, aircraft, platforms or other manmade structures at sea, operating for the purpose of disposal of such matter or derived from the treatment of such wastes or other matter on such vessels, aircraft, platforms or structures;

(ii) placement of matter for a purpose other than the mere disposal thereof, provided that such placement is not contrary to the aims of this Convention.

UNCLOS III 1982 regulates marine pollution in Part XII of Protection and Preservation of the Marine Environment (Article 192 - 237). This part comprehensively regulates on global and regional cooperation; technical assistance; monitoring and environmental assessment; international rules and national legislation to prevent, reduce and control pollution of the marine environment; enforcement; safeguards; ice-covered areas; responsibility and liability; sovereign immunity; and obligations under other conventions on the protection and preservation on the marine environment. This part shall be read in conjunction to Part III of UNCLOS III 1982 on Straits Used for International Navigation and other international law regimes.

Every state has the obligation to protect and preserve the marine environment (Article 192 of UNCLOS III 1982). States have also sovereign right to exploit their natural resources while protecting and preserving them. In order to prevent, reduce and control marine pollution, states shall take individually or jointly all actions regarding marine pollution from many sources. Referring to Article 207 - 212, marine pollution is come from five sources i.e. land-base sources, sea-bed activities, activities in area, dumping and vessel-based sources. These sources must be measured by every state including strait states to prevent, reduce and control the pollution. In fact, every state may enact its own national legislation and authority institution subject to international law of the sea and environment provisions.

\section{International Maritime Organisation Conventions}

In addition to UNCLOS III 1982, there are several international instrument related to marine pollution in the strait. Mostly, these international instruments are sourced from International Maritime 
Organisation (IMO). Mary George lists down the IMO conventions relating to prevention, reduction and controlling of marine pollution as follows (Mary George, 2008):

1. The International Convention for the Prevention of Pollution From Ships 1973 as modified by the Protocol 1978 (MARPOL 73/78);

2. The 1997 Protocol to the MARPOL $73 / 78$ concerning the prevention of air pollution from ships;

3. The International Convention on Oil Pollution Preparedness, Response and Cooperation (the 1990 OPRC);

4. The Protocol on Preparedness, Response and Cooperation to Pollution Incidents by Hazardous and Noxious Substances (The 2000 HNS Protocol);

5. The International Convention Relating to Intervention on the High Sea in Cases of Oil Pollution 1969 (The 1969 Intervention Convention);

6. The 1973 Protocol relating to the International Convention 1969 on Intervention on the high seas in cases of marine pollution by substances other than oil;

7. The International Convention on the Control of Harmful Anti-Fouling Systems for Ships (The 2001 AFS Convention);

8. The 2004 Ballast Water Convention;

9. The Convention on the Prevention of Marine Pollution by Dumping of Wastes and Other Matter (The 1972 London Conventions); and

10. The 1996 Protocol to the 1972 London Convention.

These additional instruments regarding prevention, reduction and controlling of marine pollution, anyhow, has made international instruments of marine pollution become more complex. Littoral states of the Malacca Straits like Indonesia, Malaysia and Singapore must comply with those instruments. Although it is believed that not all related conventions have ratified by respective country, application of International Customary Law has made them to comply the conventions (see Table 1.1).

There are also other IMO Conventions indirectly related to Marine Pollution Management. They are as follows:

1. International Convention on Civil Liability for Oil Pollution Damage 1969 (CLC) as modified by the 1992 Protocol (the 1992 CLC); and

2. the 1971 International Convention on the Establishment of an International Fund for Compensation for Oil Pollution Damage (1971 Fund Convention) as modifief by the 1992 Protocol (The 1992 Fund Convention).

These two conventions have same important with the former ten IMO conventions above.

Table 1.1: Ratifications of IMO Conventions Relating to Prevention, Reducing and Controling of Marine Pollution

\begin{tabular}{|c|l|c|c|c|}
\hline No. & \multicolumn{1}{|c|}{ IMO Conventions } & Indonesia & Malaysia & Singapore \\
\hline 1. & MARPOL 73/78 & Yes & Yes & Yes \\
\hline 2. & The 1997 Protocol on & Yes & Yes & Yes \\
\hline
\end{tabular}




\begin{tabular}{|c|c|c|c|c|}
\hline & MARPOL 73/78 & & & \\
\hline 3. & The 1990 OPRC & No & Yes & Yes \\
\hline 4. & The 2000 HNS Protocol & No & Yes & Yes \\
\hline 5. & $\begin{array}{l}\text { The } 1969 \text { Intervention } \\
\text { Convention }\end{array}$ & No & No & No \\
\hline 6. & $\begin{array}{l}\text { The } 1973 \text { Protocol on The } \\
1969 \text { Intervention Convention }\end{array}$ & No & No & No \\
\hline 7. & The 2001 AFS Convention & No & Yes & Yes \\
\hline 8. & $\begin{array}{l}\text { The } 2004 \text { Ballast Water } \\
\text { Convention }\end{array}$ & No & Yes & No \\
\hline 9. & $\begin{array}{l}\text { The } 1972 \text { London } \\
\text { Conventions }\end{array}$ & No & No & No \\
\hline 10. & $\begin{array}{l}\text { The } 1996 \text { Protocol to the } 1972 \\
\text { London Convention }\end{array}$ & No & No & No \\
\hline 11. & The 1969 CLC & Yes & Yes & Yes \\
\hline 12. & $\begin{array}{l}\text { The } 1992 \text { Protocol on the } \\
1969 \text { CLC }\end{array}$ & Yes & Yes & Yes \\
\hline 13. & The 1992 Fund Convention & No & Yes & Yes \\
\hline & $\begin{array}{l}\text { Number of IMO Conventions } \\
\text { and Protocols ratified }\end{array}$ & 4 & 9 & 8 \\
\hline
\end{tabular}

\section{Littoral States National Legal Regime To Prevent, Reduce And Control Of Marine Pollution}

Nationally, each littoral state has its own regulatory and institutional framework. These regulatory and institutional frameworks specializing in marine pollution, however, are not stand alone. They are mutually connected to other regulatory and institutional sectors. At least, the sectors of marine, security and environment are sectors involved in regards of marine pollution. Other sectors may be involved depending to case-by-case situations.

In regards to Indonesia national instruments, Indonesia has ratified UNCLOS III 1982 through Law No. 3/1985. This ratification has made Indonesia commitment to protect and preserve marine environment. Although without further regulation, ratification through Law No. 3/1985 is enough to make UNCLOS III 1982 apply in this country. However, to strengthen this provision, Indonesia has enacted several additional regulations as follows:

1. Law No. 5/1983 on Indonesia Exclusive Economic Zone (EEZ);

2. Law No. 6/1996 on Indonesian Territorial Water;

3. Law No. 32/2009 on Protection and Preservation of Living Environment;

4. Law No. 41/1999 on Forestry;

5. Law No. 27/2007 on Administration of Coastal Areas and Smaller and Outer Islands as amended with Law No. 1/2014;

6. Law No. 31/2004 on Fisheries as amended with Law No. 45/2009; and

7. Law No. 17/2008 on Shipping. 
All those Indonesia national regulations have their own speciality regarding sources-based pollution and its legal enforcer related to marine pollution in strait area. To know more detail about this, please see Table 1.2 below.

Table 1.2: Indonesia Regulation and Institutional Agency on Marine Pollution

\begin{tabular}{|c|c|c|c|}
\hline Regulation & Pollution Sources & Sanction & Institution \\
\hline $\begin{array}{l}\text { Law No. 5/1983 on } \\
\text { Indonesia EEZ }\end{array}$ & $\begin{array}{l}\text { Pollution from } \\
\text { activities in area }\end{array}$ & $\begin{array}{l}\text { Criminal sanction, } \\
\text { fine, civil remedies }\end{array}$ & Indonesia Navy \\
\hline $\begin{array}{l}\text { Law No. 6/1996 on } \\
\text { Indonesian } \\
\text { Territorial Water }\end{array}$ & $\begin{array}{l}\text { Sea-bed activities, } \\
\text { activities in area, } \\
\text { dumping and vessel- } \\
\text { based sources }\end{array}$ & - & $\begin{array}{l}\text { Central government, } \\
\text { municipal } \\
\text { government and the } \\
\text { Police. }\end{array}$ \\
\hline $\begin{array}{l}\text { Law No. 32/2009 on } \\
\text { Protection and } \\
\text { Preservation of } \\
\text { Living Environment }\end{array}$ & Land-based pollution & $\begin{array}{l}\text { Administrative } \\
\text { sanction, criminal } \\
\text { sanction, } \\
\text { sanction and civil } \\
\text { remedies }\end{array}$ & $\begin{array}{l}\text { Central government, } \\
\text { municipal } \\
\text { government and the } \\
\text { Police. }\end{array}$ \\
\hline $\begin{array}{l}\text { Law No. 41/1999 on } \\
\text { Forestry }\end{array}$ & $\begin{array}{l}\text { Land-based pollution } \\
\text { and atmospheric } \\
\text { pollution }\end{array}$ & $\begin{array}{l}\text { Administrative } \\
\text { sanction, criminal } \\
\text { sanction, } \\
\text { sanction and civil } \\
\text { remedies }\end{array}$ & $\begin{array}{l}\text { Central government, } \\
\text { municipal } \\
\text { government and the } \\
\text { Police. }\end{array}$ \\
\hline $\begin{array}{l}\text { Law No. 27/2007 on } \\
\text { Administration of } \\
\text { Coastal Areas and } \\
\text { Smaller and Outer } \\
\text { Islands as amended } \\
\text { with Law No. } \\
1 / 2014\end{array}$ & $\begin{array}{l}\text { Land-based pollution, } \\
\text { Sea-bed activities and } \\
\text { Activities in area }\end{array}$ & $\begin{array}{l}\text { Administrative } \\
\text { sanction, criminal } \\
\text { sanction, } \\
\text { sanction and civil } \\
\text { remedies }\end{array}$ & $\begin{array}{l}\text { Central government, } \\
\text { municipal } \\
\text { government and the } \\
\text { Police. }\end{array}$ \\
\hline $\begin{array}{l}\text { Law No. 31/2004 on } \\
\text { Fisheries as } \\
\text { amended with Law } \\
\text { No. 45/2009 }\end{array}$ & $\begin{array}{l}\text { Dumping and vessel- } \\
\text { based sources }\end{array}$ & $\begin{array}{l}\text { Administrative and } \\
\text { criminal sanction }\end{array}$ & $\begin{array}{l}\text { Indonesia Navy, } \\
\text { Indonesia Territorial } \\
\text { Water Police, Civil } \\
\text { Servant Investigator } \\
\text { under the Ministry of } \\
\text { Sea and Fishery. }\end{array}$ \\
\hline $\begin{array}{l}\text { Law No. } 17 / 2008 \text { on } \\
\text { Shipping. }\end{array}$ & $\begin{array}{l}\text { Dumping and vessel- } \\
\text { based sources }\end{array}$ & $\begin{array}{l}\text { Administrative } \\
\text { sanction, criminal } \\
\text { sanction, } \\
\text { sanction and civil } \\
\text { remedies }\end{array}$ & $\begin{array}{l}\text { Indonesia Navy, } \\
\text { Indonesia Territorial } \\
\text { Water Police, Civil } \\
\text { Servant Investigator } \\
\text { under the Ministry of } \\
\text { Sea and Fishery. }\end{array}$ \\
\hline
\end{tabular}

From those regulations, only Law No. 17/2008 on Shipping that has direct provision on preventing, reducing and controlling of marine pollution especially from shipping. Article 169 requires ship owners and operators to fulfil the requirement of management of safety and pollution prevention. This requirement further is regulated by subsidiary legislation subject to international and national legal regimes that apply. Certificate of that management will be issued by the authority in the form of Document of Compliance (DOC) for ship company and Safety Management Certificate for the ship. 
Similar to Indonesia, Malaysia has also legislative frameworks for regulation on marine pollution as mentioned in Table 4.3. The most favor regulation used by this country against marine pollution is Environmental Quality Act 1974. It is because this Act covers all sources of pollution (a one-size-fits-all regulation). Although Environmental Quality Act 1974 is the main regulation for pollution, other acts or regulations are still also applied.

Besides Environmental Quality Act 1974, there are also other acts that have specific provisions on preventions, reduction and control of marine pollution. They are Merchant Shipping Ordinance 1952 and Exclusive Economic Zone Act 1984 (EEZ Act). Section 306L - 306Q of the Merchant Shipping Ordinance 1952 regulates the issuance of certificate and obligation to hold certificate for all ship as compliance on marine pollution control and management. Meanwhile, EEZ Act adopts definition of dumping from UNCLOS 1982 and civil liability and burden sharing in its provisions.

Table 1.3: Malaysia Regulation and Institutional Agency on Marine Pollution

\begin{tabular}{|c|c|c|c|}
\hline Regulation & Pollution Sources & Sanction & Institution \\
\hline $\begin{array}{lr}\text { The } & \text { Merchant } \\
\text { Shipping } & \text { Ordinance } \\
1952 & \end{array}$ & $\begin{array}{l}\text { Dumping and vessel- } \\
\text { based sources }\end{array}$ & $\begin{array}{l}\text { Administrative, } \\
\text { fine }\end{array}$ & $\begin{array}{l}\text { Prime Minister } \\
\text { Department/Ministry of } \\
\text { Natural Resources and } \\
\text { Environment, Malaysia } \\
\text { Maritime Enforcement } \\
\text { Agency (MMEA) }\end{array}$ \\
\hline $\begin{array}{l}\text { Continental Shelf Act } \\
1966\end{array}$ & $\begin{array}{l}\text { Sea-bed activities and } \\
\text { activities in area }\end{array}$ & $\begin{array}{l}\text { Fine, criminal } \\
\text { imprisonment }\end{array}$ & $\begin{array}{l}\text { Ministry of Natural } \\
\text { Resources } \\
\text { Environment, } \\
\text { Maritime andaysia } \\
\text { Agency (MMEA) }\end{array}$ \\
\hline $\begin{array}{l}\text { Environmental } \\
\text { Quality Act } 1974\end{array}$ & \begin{tabular}{lr} 
Land-based & \multicolumn{2}{c}{ pollution, } \\
sea-bad activities, \\
activities in area, \\
dumping and vessel- \\
based sources
\end{tabular} & $\begin{array}{l}\text { Fine, criminal } \\
\text { imprisonment }\end{array}$ & $\begin{array}{lr}\text { Ministry of } & \text { Natural } \\
\text { Resources } & \text { and } \\
\text { Environment } & \text { (Director } \\
\text { General of } & \text { Environment } \\
\text { Quality) } & \end{array}$ \\
\hline $\begin{array}{l}\text { Exclusive Economic } \\
\text { Zone Act } 1984\end{array}$ & $\begin{array}{lr}\text { Dumping, vessel-based } \\
\text { sources, } & \text { sea-bad } \\
\text { activities and } & \text { activities } \\
\text { in area } & \end{array}$ & $\begin{array}{l}\text { Fine, criminal } \\
\text { imprisonment }\end{array}$ & 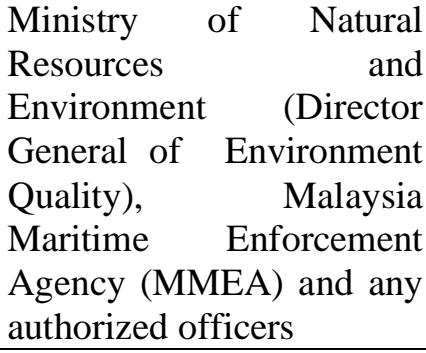 \\
\hline $\begin{array}{l}\text { Merchant Shipping } \\
\text { (Oil Pollution) Act } \\
1994\end{array}$ & $\begin{array}{l}\text { Dumping, vessel-based } \\
\text { sources, }\end{array}$ & $\begin{array}{l}\text { Fine, criminal } \\
\text { imprisonment, civil } \\
\text { liability }\end{array}$ & $\begin{array}{lr}\begin{array}{l}\text { Ministry of } \\
\text { Malaysia }\end{array} & \text { Transport, } \\
\text { Enforcement } & \text { Maritime } \\
\text { (MMEA) } & \end{array}$ \\
\hline Fisheries Act 1985 & $\begin{array}{l}\text { Dumping, activities in } \\
\text { area }\end{array}$ & $\begin{array}{l}\text { Fine, criminal } \\
\text { imprisonment }\end{array}$ & $\begin{array}{lr}\text { Ministry of } & \text { Agricultures } \\
\text { and Agro-based } & \text { Industry, } \\
\text { Malaysia } & \text { Maritime } \\
\text { Enforcement } & \text { Agency } \\
\text { (MMEA) } & \end{array}$ \\
\hline
\end{tabular}


Different to Indonesia and Malaysia, Singapore has least legislative framework on prevention, reduction and control of marine pollution. However, Singapore effectively regulates marine pollution based on internal situation in its sea or water. It ratifies several conventions and then applies them to the country without further making any legislative frameworks. There are only two regulations enacted and has direct effect to prevent, reduce and control marine pollution. They are as mentioned in Table 1.4.

Table 1.4: Singapore Regulation and Institutional Agency on Marine Pollution

\begin{tabular}{|c|c|c|c|}
\hline Regulation & Pollution Sources & Sanction & Institution \\
\hline $\begin{array}{l}\text { Prevention of } \\
\text { Pollution of the Sea } \\
\text { Act } 1990\end{array}$ & $\begin{array}{ll}\text { Land-based } & \text { sources, } \\
\text { vessel-based } & \text { sources, } \\
\text { dumping } & \end{array}$ & $\begin{array}{l}\text { Fine, criminal } \\
\text { imprisonment, civil } \\
\text { liability }\end{array}$ & $\begin{array}{l}\text { Maritime and Port } \\
\text { Authority of Singapore } \\
\text { (MPA) }\end{array}$ \\
\hline $\begin{array}{l}\text { Merchant Shipping } \\
\text { (Civil Liability and } \\
\text { Compensation for Oil } \\
\text { Pollution) Act }\end{array}$ & $\begin{array}{l}\text { Dumping, vessel-based } \\
\text { sources }\end{array}$ & $\begin{array}{l}\text { Fine, criminal } \\
\text { imprisonment, civil } \\
\text { liability }\end{array}$ & $\begin{array}{l}\text { Maritime and Port } \\
\text { Authority of Singapore } \\
\text { (MPA) }\end{array}$ \\
\hline
\end{tabular}

Prevention of Pollution of the Sea Act 1990 is the Act that gives effect to the International Convention for the Prevention of Pollution from Ships 1973 as modified and added to by the Protocol of 1978. Meanwhile Merchant Shipping (Civil Liability and Compensation for Oil Pollution) Act 1998 is the Act to give effect to the International Convention on Civil Liability for Oil Pollution Damage 1992 and to the International Convention on the Establishment of an International Fund for Compensation for Oil Pollution Damage 1992. Both Acts are related to the prevention, reduction and control of pollution of the sea and pollution from ships.

\section{Conclusion And Recommendations}

As conclusion, the littoral states have realized the importance of the Strait of Malacca for their economic interests. The strategic location of the Strait of Malacca cannot be denied for the purpose of international navigation. Indonesia, Malaysia and Singapore, so far, have entered many agreements regarding the boundary of territorial sea and continental shelf in the Strait of Malacca and also the Strait of Singapore. What the littoral states have been done on the Strait of Malacca should be appreciated. They have gone thorough meetings and several agreements have been made since 1970s. They realized the importance of the Strait of Malacca including in economic, geopolitic, security and environmental matters.

In terms of environmental matter or marine pollution, these littoral states have concerned about this since long ago. However, serious initiative to make Strait of Malacca safety and secure was just made in 2004. It is the International Maritime Organization (IMO) initiating to ask the 
littoral states to cooperate to settle issues in the Strait of Malacca. From then, annual meetings have been made amongst Indonesia, Malaysia and Singapore. Kuala Lumpur meeting in 2006 provides positive result The Cooperative Mechanism was born from this meeting and being landmark principle to prevent, reduce and control of marine pollution.

In addition and regarding to the traffic limitation schemes, it is also important to consider the cross traffic limitation schemes from east coast of Sumatera to west coast of Malay Peninsula or vice versa. Many commercial and passenger ships cross the Strait of Malacca daily. It may be a danger if this traffic limitation scheme is not determined. If collision happens between large vessel and passenger ship, surely there will be pollution in the Strait and this is something that the world does not want.

\section{References}

Abdul Haseeb Ansari, Prevention, Abatement and Control of Pollution of Straits: An Appraisal With Special Reference To The Straits Of Malacca, [2005] 3 MLJ XXXVII.

Adirini Pujayanti, Budaya Maritim, Geo-Politik dan Tantangan Keamanan Indonesia, Bagian Kesatu, 2011, http://berkas.dpr.go.id/pengkajian/files/buku_lintas_tim/buku-lintas-tim-3.pdf, 15 May 2014

A. G. Mazlan, C C Zaidi, W M Wan-Lotfi \& B H R Othman, On the Current Status of Coastal Marine Biodiversity in Malaysia, Indian Journal of Marine Sciences, Vol. 34(1) pp 76-87, 2005

Alan Tan Khee Jin, Control of Pollution in the Straits Of Malacca and Singapore: Modalities of Co-operation - Rapporteur's Report, Singapore Journal of International \& Comparative Law 2, pp 269-283, 1998.

Australia - Papua New Guinea Treaty on sovereignty and maritime boundaries in the area between the two countries, including the area known as Torres Strait, and related matters, 18 December 1978.

Bernard H. Oxman, Observations on the Interpretation and Application of Article 43 of UNCLOS with Particular Reference to the Straits of Malacca and Singapore, Singapore Journal of International \& Comparative Law, Vol. 2, Issue 2, pp. 408-426, 1998

Capt Rakish Suppiah, Oil Spills Responding To the Risk Portrayed In the Straits Of Malacca, Malayan Law Journal Articles [2009] 1 MLJ Cxlvi

Carrie R. Woolley, Piracy and Sovereign Rights: Addressing Piracy in the Straits of Malacca without Degrading the Sovereign Rights of Indonesia and Malaysia, Santa Clara Journal of International Law, Vol. 8, Issue 2 (2010), pp. 447-472

Chua Thia-Eng, Ingrid R.L. Gorre, S. Adrian Ross, Stella Regina Bernad, Bresilda Gervacio, and M. Corazon Ebarvia, The Malacca Straits, Marine Pollution Bulletin, Vol. 41, Nos. 1-6, pp 160-178, Elsevier Science Ltd., 2000

Chua Thia-Eng, Marine Pollution Prevention and Management in The East Asian Seas: A Paradigm Shift in Concept, Approach and Methodology, Marine Pollution Bulletin 39, Vol. 39, Nos. 1-12, pp 80-88, Elsevier Science Ltd., 1999.

E.D. Brown, The International Law of the Sea Volume II: Documents, Cases and Tables, Dartmouth Publishing Company Limited, 1994

European Institute for Asian Studies (EIAS) Briefing Seminar Report, the Straits of Malacca: Managing Strategic Waters in South-East Asia, 2011

Goh Kim Chuan \& Mark Cleary, Environment and Development in the Straits of Malacca, Vol. 10, Routledge, 2005 (GOOGLE BOOK)

George, Mary, Legal Regime of the Straits of Malacca and Singapore, Lexis Nexis-Singapore, 2008. 
H.M Ibrahim \& Nazery Khalid, Growing Shipping Traffic In the Strait of Malacca: Some Reflections on the Environmental Impact, Maritime Institute Malaysia, 2007

Indonesia - Malaysia Continental Shelf Boundary 1969.

Indonesia - Malaysia Territorial Sea Boundary 1971.

Indonesia - Singapore Territorial Sea Boundary 1974.

Jeanine B. Womble, Freedom of Navigation, Environmental Protection, and Compulsory Pilotage in Straits Used for International Navigation, Naval Law Review, Vol. 61, pp 134-15, 2012

Koji Sekimuzu, Jean-Claude Sainlos \& James N. Paw, The Marine Electronic Highway in the Straits of Malacca and Singapore - An Innovative Project for the Management of Highly Congested and Confined Waters, International Maritime Organization, 2001.

Maki Teramoto, Shu Yeong Queck \& Kouhei Ohnishi, Specialized Hydrocarbonoclastic Bacteria Prevailing in Seawater around a Port in the Strait of Malacca, PLOS ONE, Vol. 8, Issue, 6, 2013

Mark Heah Eng Siang, Implementation of Mandatory Ship Reporting in the Malacca and Singapore Straits, Singapore Journal of International \& Comparative Law 2, pp 345 - 345, 1999

Mark J. Valencia, Malaysia and the Law of the Sea: The Foreign Policy Issues, the Option and Their Implications, Institute of Strategic and International Studies, 1991

Mary George, Adequacy of National Laws for Malaysian Ocean Governance for the Next Decade, International Journal of Legal Information, Vol. 40, Issue 1 and 2, pp 202-256, 2012

Mohd Hazmi Bin Mohd Rusli, Protecting Vital Sea Lines Of Communication: A Study Of The Proposed Designation of The Straits of Malacca and Singapore as A Particularly Sensitive Sea Area, Ocean \& Coastal Management 57, pp 79-94, Elsevier Ltd., 2012.

Mohd Hazmi Bin Mohd Rusli, Navigational Hazards in International Maritime Chokepoints: A Study of The Straits Of Malacca And Singapore, Journal of International Studies, Vol. 8, 2012

Mohd Hazmi Bin Mohd Rusli, The Legal Feasibility Of The Imposition Of A Traffic Limitation Scheme In Straits Used For International Navigation: A Study Of The Straits Of Malacca And Singapore, International Journal Of Humanities And Social Science, Vol. 1, No. 6, pp 122-130, 2011

Mokhzani Zubir, The Strategic Value of the Strait Of Malacca, Analysis paper, Maritime Institute of Malaysia, 2004

Nazery Khalid, With a Little Help from My Friends: Maritime Capacity-building Measures in the Straits of Malacca, Contemporary Southeast Asia: A Journal of International and Strategic Affairs 31, No. 3, 2009

Nazery Khalid \& Mohd Nizam Basiron, Securing Energy Transportation in the Straits of Malacca, Ocean Yearbook, Vol. 22, pp. 513-534, 2008

Raul (Pete) Pedrozo, Encroachment on Navigational Freedoms, International Law Studies. US Naval War College, Vol. 84, Issue 1, pp 85-96, 2008

Robert Beckman, Singapore Strives to Enhance Safety, Security, and Environmental Protection in Its Ports and in the Straits of Malacca and Singapore, Ocean and Coastal Law Journal, Vol. 14, Issue 2, pp 167-200, 2009

Robert C Beckham, The International Legal Regime Governing The Safety Of Navigation And The Prevention Of Pollution In International Straits, Singapore Journal of International \& Comparative Law 2, pp 350 - 392, 1998

R.R. Churchill \& A.V. Lowe, The Law of the Sea, $3^{\text {rd }}$ Edition, Manchester University Press, 1999

S Jayakumar, Straits of Malacca and Singapore: Meeting the Challenges Ahead, Singapore Journal of International \& Comparative Law 2, pp 427- 432, 1998

Sutarji Kasmin, Enforcing Ship-Based Marine Pollution for Cleaner Sea in The Strait Of Malacca, Environment Asia 3, Special Issue, pp 61-65, 2010.

The Geographer, Indonesia - Malaysia Continental Shelf Boundary, International Boundary Study Series A : Limits in the Seas No. 1, 1970

The Geographer, Indonesia - Malaysia Territorial Sea Boundary, International Boundary Study Series A: Limits in the Seas No. 50, 1970 
Tommy H. Purwaka, Control of Marine Pollution in the Straits of Malacca and Singapore: Modalities for International Co-Operation, Singapore Journal of International \& Comparative Law 2, pp 452-463, 1998.

United Kingdom - French Republic Treaty of Canterbury on Concerning The Construction And Operation By Private Concessionaires Of A Channel Fixed Link, 12 February 1986.

United Kingdom - French Republic Treaty on the Delimitation of the Continental Shelf in the Area East of 30 Minutes West of the Greenwich Meridian, 28 June 1982.

Wan Siti Adibah Wan Dahalan, Zinatul A. Zainol, Jady@Zaidi Hassim, \& Chia Huey Ting, ENavigation in the Straits of Malacca and Singapore, International Journal of Computer Theory and Engineering, Vol. 5, No. 3, pp 388-390, 2013

Wan Siti Adibah Wan Dahalan, Zinatul Ashiqin Zainol, Noor Inayah Yaa'kub \& Noridayu Md Kassim, Corporate Social Responsibility (CSR) From Shipping Companies in the Straits of Malacca and Singapore, International Journal of Business and Society, Vol. 13, No. 2, pp 197 208, 2012

Y. S.Hii, A. T. Law, F. M. Yusoff \& Ors, The Straits Of Malacca: Hydrological Parameters, Biochemical Oxygen Demand And Total Suspended Solids, Journal Of Sustainability Science And Management, Vol. 1(1), pp 1-14, 2006

MPP-EAS, Marine Pollution Management In The Malacca/Singapore Straits: Lessons Learned, GEF/UNDP/IMO Regional Programme for the Prevention and Management of Marine Pollution in the East Asian Seas, 1998

http://www.un.org/

http://www.cooperativemechanism.org.my

http://www.thejakartapost.com

https://www.menas.co.uk 